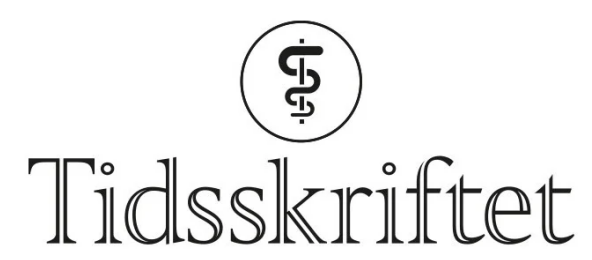

DEN NORSKE LEGEFORENING

\title{
Kronisk inflammatorisk tarmsykdom og covid-19
}

DEBATT

\section{BJØRN MOUM}

moum.bjorn@gmail.com

Bjørn Moum er professor og spesialist i fordøyelsessykdommer, med spesiell forskningsinteresse innenfor klinisk epidemiologi og behandling av Crohns sykdom og ulcerøs kolitt.

Forfatteren har fylt ut ICMJE-skjemaet og oppgir ingen interessekonflikter.

\section{Pasienter med kronisk inflammatorisk tarmsykdom behandles ofte med immundempende medikamenter. Det gjør pasientene mer utsatt for infeksjon.}

Mange pasienter med kronisk inflammatorisk tarmsykdom (IBD) henvender seg nå til sine behandlere og spør om de har økt risiko for covid-19 og om de har høyere risiko for et alvorlig forløp dersom de skulle få sykdommen. Min erfaring så langt er at få spør om de bør stoppe behandlingen av tarmsykdommen.

\section{$\emptyset \mathrm{kt}$ risiko for covid-19?}

Pasienter med inflammatorisk tarmsykdom i remisjon har ikke økt risiko for å bli smittet med sars-CoV-2 (1-3). Imidlertid mangler det data på hvordan den immunmodulerende og den immunsupprimerende behandlingen påvirker risikoen for alvorlig forløp dersom man blir smittet. Foreløpig er det dokumentert at eldre og personer med andre sykdommer (hjerte- og karsykdommer, diabetes, kronisk luftveissykdom og kreft) og røkere er utsatt for mer alvorlig infeksjon og har høyere dødelighet av covid-19 (4-7.).

Ettersom den generelle risikoen for alvorlige infeksjoner (som luftveisinfeksjoner) er litt $\emptyset \mathrm{kt}$ hos pasienter som får immunsupprimerende og/eller biologisk behandling (1-3), er det nærliggende å anta at dette også gjelder ved covid-19. Vi har foreløpig ikke grunnlag for å si at covid-19 medfører økt risiko for residiv av inflammatorisk tarmsykdom. Imidlertid er min kliniske erfaring at sesonginfluensa kan gi milde symptomer av tarmsykdom den første uken av sykdomsforløpet. Dette skjer oftest hos pasienter med ulcerøs kolitt.

\section{Behandlingsanbefalinger}


5-aminosalisylsyre-preparater (balsalazid, mesalazin) anses som trygge å bruke for personer med kronisk inflammatorisk tarmsykdom, også under et sykdomsforløp med covid-19 (1,2).

Steroider som prednison og prednisolon bør reduseres og seponeres hvis mulig. Kortikosteroider synes generelt å øke risikoen for sekundærinfeksjoner ved influensainfeksjoner. Det er vist nedsatt eliminasjon av sars-CoV-2 samtidig med komplikasjoner av kortikosteroidbehandling hos overlevende (1-3).

Tiopuriner (6-merkaptopurin, azatioprin) hemmer kroppens immunrespons på virusinfeksjoner. Er det dermed nødvendig å seponere dem ved virusinfeksjoner, som for eksempel vanlig sesonginfluensa? Og vil det være nødvendig ved covid-19? Litt avhengig av dosering tar det flere måneder før tiopuriner er eliminert fra kroppen etter inntak, og på kort sikt vil det derfor ikke hjelpe å seponere dem. Ved en virusinfeksjon som lett og moderat influensasykdom er det altså ikke grunn til å stoppe behandlingen $(\underline{2}, 3)$. På grunn av usikkerheten som råder rundt covid-19, er det derimot anbefalt å stoppe tiopurinbehandling (1-3). Hos alvorlig og kritiske syke pasienter med kronisk inflammatorisk tarmsykdom er risikoen stor for bivirkninger og medikamentelle interaksjoner ved bruk av tiopuriner og metotreksat. Disse medikamentene skal derfor stoppes ved samtidig kritisk covid-19-sykdom (1,3)-(7).

Anbefalt dosering av azatioprin når det gis som antiinflammatorisk behandling for kronisk inflammatorisk tarmsykdom er 2,5 mg pr kg kroppsvekt daglig (ㅁ). Ved Oslo universitetssykehus, Ullevål brukes azatioprin hovedsakelig som tilleggsbehandling i en lav dose på $100 \mathrm{mg}$ daglig for å hindre antistoffdannelse hos pasienter som bruker TNF-alfahemmere $(9, \underline{10})$. En slik lav dose av medikamentet vil derfor elimineres langt raskere enn azatioprin tenkt som antiinflammatorisk behandling i anbefalt dose.

\section{«Det mangler data på hvordan den immunmodulerende og den immunsupprimerende behandlingen påvirker risikoen for alvorlig forløp dersom man blir smittet»}

Biologiske legemidler som brukes ved inflammatorisk tarmsykdom, er TNF-alfa-hemmere (adalimumab, infliksimab, golimumab), ustekinumab og vedolizumab. Disse anses generelt som trygge. Det anbefales ikke å stoppe denne behandlingen selv om pasienten rammes av covid-19. Biologiske legemidler har en langvarig effekt, ofte gjennom flere måneder, det vil si at effekten av behandlingen vil vedvare selv i lang tid etter at behandlingen er seponert. Tofacitinib, som tilhører medikamentgruppen Januskinasehemmere (JAK-hemmere), har i likhet med tiopuriner en hemmende effekt på den naturlige immunresponsen ved virusinfeksjoner. Denne behandlingsformen bør man derfor vurdere å seponere ved covid-19-infeksjon, og definitivt ved covid-19 sykdom.

Hvis det er indikasjon for å starte biologisk behandling hos en pasient med inflammatorisk tarmsykdom, bør man vurdere oppstartstidspunktet nøye. Er det forsvarlig å utsette behandlingen under den pågående covid-19-epidemien? Skal man kombinere behandlingen med tiopuriner eller metotreksat? I de tilfellene der oppstart er nødvendig, kan det være at man bør velge adalimumab uten immunsupprimerende tilleggsbehandling.

Den europeiske organisasjonen for Crohns sykdom og ulcerøs kolitt (ECCO) fraråder å bytte fra infusjonsbehandling med TNF-alfa-hemmer til subkutan TNF-alfa-hemmer hos stabile pasienter, dette for å unngå sykehusbes $\emptyset \mathrm{k}$ og redusere smitterisikoen (2). Medikamentbytte bør som før kun være på grunn av manglende behandlingsrespons, tap av effekt under pågående behandling eller bivirkninger. I så fall kan bytte til subkutan behandling ha sine fordeler: Smitterisikoen reduseres når telefonkonsultasjoner delvis erstatter oppmøte på sykehus.

\section{Generelle anbefalinger}


Vi anbefaler pasienter med kronisk inflammatorisk tarmsykdom å sørge for å ha nok medisiner for sin tarmsykdom hjemme og følge de generelle smitteforebyggende tiltakene og rådene fra Folkehelseinstituttet. Ved nærkontakt med en person som har fått påvist covid-19, bør pasienter med kronisk inflammatorisk tarmsykdom følges opp i henhold til nasjonale anbefalinger. Under spesielle omstendigheter bør de ha prioritet for å testes for covid-19. De samme nasjonale karantenebestemmelser gjelder for denne pasientgruppen som for alle andre. Reiser til endemiske områder frarådes.

\section{LITTERATUR}

1. European Crohn's and Colitis Organization. 1st Interview COVID-19 ECCO Taskforce. https://eccoibd.eu/images/6_Publication/6_8_Surveys/1st_interview_COVID19\%20ECCOTaskforce_published.pdf Lest 31.3.2020.

2. European Crohn's and Colitis Organization. 2nd Interview COVID-19 ECCO Taskforce. https://eccoibd.eu/images/6_Publication/6_8_Surveys/2nd_Interview_COVID19_ECCO_Taskforce_published.pdf/ Lest 31.3.2020.

3. IOIBD Update on COVID19 for Patients with Crohn's Disease and Ulcerative Colitis. Update: 26 March 2020. https://www.ioibd.org/ioibd-update-on-covid19-for-patients-with-crohns-disease-andulcerative-colitis/ Lest 31.3.2020.

4. Centers for Disease Control and Prevention. People Who Are at Higher Risk for Severe Illness. https://www.cdc.gov/coronavirus/2019-ncov/specific-groups/people-at-higher-risk.html/ Lest 31.3.2020.

5. Borén HK, Kjøstolfsen GH, Aaløkken TM et al. En mann i 9o-årene med feber og tørrhoste. Tidsskr Nor Legeforen 2020;140. doi: 10.4045/tidsskr.20.0218. [CrossRef]

6. Ruan Q Yang K, Wang W et al. Clinical predictors of mortality due to COVID-19 based on an analysis of data of 150 patients from Wuhan, China. Intensive Care Med 2020; 46. doi:10.1007/soo134020-05991-x. [PubMed][CrossRef]

7. Baud D, Qi X, Nielsen-Saines K et al. Real estimates of mortality following COVID-19 infection. Lancet Infect Dis 2020; 20: S1473-3099(20)30195-X. [PubMed][CrossRef]

8. Torres J, Bonovas S, Doherty G et al. ECCO Guidelines on Therapeutics in Crohn's Disease: Medical Treatment. J Crohn's Colitis 2020; 14: 4-22. [PubMed][CrossRef]

9. Roblin X, Boschetti G, Williet $\mathrm{N}$ et al. Azathioprine dose reduction in inflammatory bowel disease patients on combination therapy: an open-label, prospective and randomised clinical trial. Aliment Pharmacol Ther 2017; 46:142-9. [PubMed][CrossRef]

10. Williet N, Roblin X. Trend towards dose reduction of azathioprine as monotherapy in inflammatory bowel disease patients: what about for combination therapy? Therap Adv Gastroenterol 2017; 10:5-10. [PubMed][CrossRef]

Publisert: 8. april 2020. Tidsskr Nor Legeforen. DOI: 10.4045/tidsskr.20.0230

Mottatt 18.3.2020, første revisjon innsendt 26.3.2020, godkjent 7.4.2020.

(C) Tidsskrift for Den norske legeforening 2023. Lastet ned fra tidsskriftet.no 26. april 2023. 